\title{
REFORM OF CRIMINAL PROCEDURE, WITH REFER- ENCE PARTICULARLY TO THE INDICTMENT
}

Many articles have been published within recent years, both in popular and in legal magazines, criticizing the administration of our criminal law. There have been many attempts to show that criminal procedure is in a deplorable state, that technicalities and forms are the essential parts and that justice is dispensed with. The courts have been the objects of great criticism, the writers seeming to have been actuated by the idea that the courts of the United States could make and unmake laws at their discretion. These articles, though serving the good purpose of attracting the attention of the public to a state of affairs which, like everything else in this mundane sphere, may be bettered by the efforts of people who will really study the subject, have been very unfair, in that they have placed all the blame on the judges alone. The writers have not analyzed the cases which they cite; they state the facts in a manner which is least likely to appear to the untrained mind as leading to the decision and then say: "See what the court decided!" The public which reads these articles is not to be blamed for the adverse attitude which is taken towards the courts. The whole of any case is not accessible to the ordinary reader and he is prone to believe what he is told.

These popular writers have not analyzed the cases and have not attempted to find where the fault really lies. The judges are on the bench to administer the law as they find it to be, not as they would like it to be. There are rules of law and procedure which may appeal to the judges as perfectly foolish, as serving no good end and obstructing justice, but if they are the law, the courts must apply them. One who studies the cases is frequently struck by the ingenuity which some judges display in avoiding the application of technical rules to particular facts. It sometimes happens, however, that the law, though absurd, is so definite that it must show its absurdity in some particular cases. A court was severely criticized for its decision in this case: a statute made it grand lar- 
ceny to steal "a cow or animal of the cow kind." A man stole a steer and there was an attempt to convict him under this statute for grand larceny. The court held that a cow was a female animal and the steer was a male animal and so not "of the cow kind," and therefore no conviction could be had. The court was not to blame because the legislature made an absurd distinction between male and female animals.

The layman feels that the law is, as it should be, almost perfect, and that, therefore, the court which reaches an apparently absurd conclusion must be mistaken in its law. The law is not perfect, and although the courts do make some mistakes, they are right more frequently than their critics in interpreting the law.

The layman, and the writer who gives him his instances where justice in the abstract sense wąs not done, are both right in their feeling that some one made a mistake, that the decision is the result of an error, but neither of them really seeks to find who caused that error. Sometimes the judge is wrong, but more frequently the fault is beyond the reach of the judge. Sometimes the fault lies in the constitution of the state, sometimes in the substantive law as declared by the legislature, more frequently in the procedure which the legislature has made mandatory on the courts, but most frequently the fatal mistake is made by some official of the court, who is so far removed from the judge, that, although the judge must force that officer to correct his errors, the judge is unable to prevent his making them or to correct them after they have been made. That officer is the public prosecutor.

This article will discuss mainly the procedure in criminal trials so far as it relates to the formal written accusation upon which a person, prosecuted for an offense which is triable before a petit jury, goes to trial. This formal accusation may be a presentment, an indictment or an information, but, in the main, the same considerations apply to each. They differ in the maniner in which they become part of the court's records, but the same tests of sufficiency and validity are for the most part applied.

At this point, it is perhaps proper to point out the practical differences which exist between procedure by information and procedure by indictment, and the similarities which exist in the two

1 Marsh v. State, 57 So. Rep. 387 (Ala., 1912). 
systems. The indictment and the information both originate with the prosecuting officer. Both are drawn by him, or his subordinates, on information given them for the most part by various persons who have been the victims of the criminal operations of some individual. The allegations of each, when charging any given offense, are practically the same, whether we compare indictments and informations in states in which both are permissible or whether we compare those which originate in different states where only one is proper. The same tests of sufficiency of averments describing persons, places and things, or alleging any matters, are applicable when the documents are brought into the trial court.

The sole difference between the two forms of procedure lies in the manner in which the two documents get into the trial courts and become part of its record. The information is taken there directly by the public prosecutor, while the indictment must first be considered by the grand jury. Theoretically the grand jury hear the evidence against the accused and cannot send him to trial unless they hear evidence which tends to prove that every. allegation of the indictment which they have before them is true. Theoretically the grand jurors know all the criminal law, know the elements of every offense and are able to differentiate between a valid and an invalid indictment. Practically, they rely entirely upon the legal knowledge of the prosecuting officer. In some states he is permitted to. be present with them, guiding them in their work; in others, he may not enter the room; but in all they rely on him for their law and in most cases they accept the facts as he chooses to present them.

The point we wish to make is that the indictment in its form, in the substance of the matters alleged, and in the evidence which is to support its allegations, is dependent upon the prosecuting officer. His knowledge of the law is what determines the various matters which must be alleged in order to constitute any offense, and his knowledge of the facts determines the descriptive matter which distinguishes the particular transaction constituting the offense. In these respects the indictment does not differ from the information; both are dependent upon the knowledge of the district attorney. The grand jury has the power, of course, to correct the prosecuting officer's mistakes both in law and facts, but 
practically they never do so. They do not know enough law to detect errors in law, and they do not hear enough of the evidence to discover mistakes in the facts averred.

In some states, the district attorney may prefer an information as of his own knowledge, based upon the testimony of witnesses who have come before him. In others the person who makes the complaint does so as of his own initiative, and swears thereto and signs it. In the latter case it is still the district attorney who selects the pertinent matter, who differentiates between the really criminal acts and those which appeared criminal to the complainant, and determines what descriptive matter.shall be placed in the accusation.

We do not intend here to hold a brief for the indictment against the information, or vice versq, but merely to point out that the responsibility for the correctness and sufficiency of each rests upon the same department of our criminal courts, the prosecuting offirer. He should, to a great extent, shoulder the blame for the delays, mis-trials and re-trials which have brought much disrepute upon the administration of criminal law.

Throughout this article, the term indictment is used to include both indictment and information, for the reason that the same considerations apply to each. In some instances "indictment" designates an indictment as distinguished from an information, but the context will show when such is the case.

The errors which may occur in ari indictment may be broadly divided into mistakes of law and mistakes of, fact. Mistakes of law are those which arise from a lack of knowledge of the district attorney of the law applicable to the particular case at hand, and they are, in turn, of two types: (I) mistakes of substantive law, and (2) mistakes of procedural law. The mistakes of substantive law are caused by the rule of procedural law that the indictment must aver all the elements of the offense for which the prosecution is being had. Therefore, unless the prosecuting officer knows all the elements of the various offenses and is careful to aver sufficient facts to show that these elements all concurred in the particular transaction under investigation, invalid indictments vill frequently be presented. Thus it is essential to the offense of rape that the victim be a person other than the wife of the accused, and the information is in- 
valid which does not aver that such is the case.? Where the statute makes a check "of or on any bank" the subject of larceny, it is not sufficient to aver that the accused stole "a check" without adding that it was "of or on some bank."

Errors of procedural law occur when the pleader fails to aver matter which the rules of procedure say shall be stated in the indictment, or when he fails to state such matter in the manner required by the rules of procedure. Procedural law sometimes requires that the indictment must conclude "against the peace and dignity of the state," and the indictment is invalid which omits these words. The indictment must be direct and certain in its averments, and an allegation that a bank official received a deposit "after the bank was insolvent" is not a sufficient averment that the bank was insolvent at the time he accepted the deposit." An omission to state that an act made a felony by statute was "feloniously" done is fatal." These instances are given to show the distinction which the writer would take between errors of substantive law and errors of procedure, although it is obvious that errors of substantive law in the indictment are also errors of procedure.

Errors in the statement of facts are those which appear when the allegations of the indictment do not correspond to the facts. Matters are alleged which never happened, and persons, places and things are misnamed or misdescribed. When the evidence fails entirely to prove the existence of some element in the transaction necessary to its criminality, an acquittal results, and rightly so. Variances in matters of description, where one state of facts is averred and another state just as criminal is proved, constitute the errors which get into the reports and which cause so much condemnation of our criminal procedure in that they, too, result in acquittals. The classical instance of this is where the man accused of stealing a pair of shoes secured a new trial because in the hurry of his departure he had appropriated two rights instead of a right and a left.'

\footnotetext{
2 People v. Miles, 9 Cal. App. 312 (1908).

${ }^{2}$ Cornm. v. Schissler, 7 Dist. 341 (Pa., I898).

'State v. Campbell, 109 S. W. Rep. 706 (Mo., 1908).

- Fleming v. State, 62 Tex. C. Rep. 653 (19rt).

- State v. Dixon, 153 S. W. Rep. 22 (Mo., I.. i.

'State v. Harris, 3 Har. 559 (Del., 184 r).
} 
Assuming that it is within the power of the prosecuting officer to avoid errors in the drawing of indictments, and leaving to a future discussion the extent to which he should be relieved of the burden thus placed upon him by the legal system, let us for a moment consider the various causes of the errors and mistakes which creep into the indictments. In the first place, the district attorney may have drawn a defective indictment intentionally, with the deliberate purpose of assisting the accused, since an error not material to the merits of the case may compel a new trial after conviction. It is to the credit of the prosecuting officers that no charges of deliberate malfeasance in this respect have ever been made against them. In many cases, the errors which appear in indictments are caused by a real doubt or lack of knowledge of both law and facts on the part of the prosecuting attorney. Haying done his best to ascertain the facts and the law applicable thereto, he still is in doubt and takes a chance. The frequency of the errors resulting from this cause are in inverse ratio to the skill, experience, and intelligence of the attorney, but they form no inconsiderable portion of the whole number of invalid indictments. The rules governing the allegations of the indictment are based upon no fundamental unchangeable principle, and the pleader is in constant difficulty. If he alleges too little, the indictment is bad, because insufficient; if he alleges too much, it is bad for uncertainty or duplicity. His only safe guides are the precedento which the supreme court of his jurisdiction has held sufficient, and if the case be a new one in the jurisdiction, in that it has arisen under a new statute, there is a probability that even with the greatest care and study he will be unable to frame an indictment which will stand the tests. On reading the cases, one feels that many times the pleader had the better of the argument, and that the court was right only because it had the last'guess. It is this large class of really doubtful cases that exposes the criminal judge, and the procedure which leaves these cases doubtful, to deserved criticism. It is this class of cases which demands the attention of those who are really interested in the subject. Contradictory and conflicting rules said to be based upon the same principle should be abrogated and it should be made possible for the pleader to make the conviction stick, who, though in doubt as to the law or as to 
certain facts, has given the accused person such notice as to secure a fair trial, and has secured the conviction. This article will deal more with these doubtiul cases than with any others.

There is no line of demarcation between those errors which are due to real doubt in the mind of the pleader and those which are due solely to his carelessness and incompetency. Say the law and the facts be at present doubtful to him, but a little attention and study will clear up both; the pleader chooses to make a gues, and, by the laws of hazard, his guesses can't be right all the time. It is impossible under the present rules for the pleider to avoid all errors, but it is certain that the more attention he pays to his business, the higher will be his percentage of correct indictmenta. It is impossible to say just how many invalid indictments are caused by carelessness, indifference, and incompetency on the part of the person writing the indictment, but they are at least as many as are due to the complexities of the law.

The results of errors in the drawing of indictments are more obvious, and have attracted more attention than have the causes thereof. If the error is discovered before trial, the trial must be delayed until the district attorney has drawn a new indictment, and the grand jury acted thereon. In jurisdictions where the information is permissible, the delay due to the necessity of awaiting action by the grand jury does not occur. The usual delay in such jurisdictions is merely the time it takes the prosecuting officer to rewrite his charge. If, on the other hand, the invalidity of the accusation is not discovered until after trial, the whole proceeding must be gone through again, provided, of course, that the verdict was against the accused, for it 80 happens that an indictment which is not good enough to be convicted on is always sufficient for the accused, if he be acquitted. Where a variance appeare in the course of the proceedings, an acquittal or a noll pros. resultes but fortunately in such cases the acquittal due to the variance does not terminate the case, and the accused may be prosecuted anew: provided that in the meanwhile the statute of limitations has not interposed its bar. Most jurisdictions, by statute, postpone the . running of. the statute of limititations in cases where the prosecution has been shown to have been defective.

It is axiomatic that the interests of the state lie in the quick 
and efficient administration of justice, particularly criminal justice. The simplest and most obvious way to remedy the present situation, which has attracted so much adverse criticism in that it results in so many mis-trials, re-trials and no trials, is to elect honest, competent and hardworking prosecuting officers. Then those errors which are due to a treasonable desire to help the accused would disappear from the reports. The errors due to a careless and superficial study of the law and the facts would disappear. Such an attorney would know the substantive law of the statute books, would ascertain the true facts and correlate the two in the acsusation. There would still appear variances due to mistakes of fact. Every lawyer knows that all the facts never come out until crossexaminations, but such variances would be reduced to a minimum. There would then remain only those errors due to the defects in our rules of procedure, and they would vary in number with the intelligence of the district attorney elected. This plan does not appeal to the typical reformer, for the reason that it would require his constant attention. It is not automatic; it is not a plan which, when put into operation, will take care of itself, and so is not frequently mentioned. This scheme does not involve the passage of any new laws, and the present trend of reform seems to be toward the curing of all evil conditions, in the law as well as in society, by legislative enactment.

There are several other possible methods of preventing and remedying defects in the branch of criminal procedure relating to indictments. The one which has attracted least attention consists in simplifying our substantive law of crimes. A little study of the criminal statutes of all but a few jurisdictions will prove to any thinking person that they have developed upon no logical principle. The definitions of offenses found there contain many matters which have but little to do with the criminality of the act. The present system of criminal law was a haphazard attempt to remedy the deficiencies of the common law. The common law defined certain crimes in certain terms. As civilization and education developed, the minds of criminals shared in the general intellectual advancement. Men found out that the doing of an act which had the same results, both to themselves and to their victim, as the commission of a defined offense, did not involve criminal 
responsibility. The legislature remedied this, by making the acts which they did criminal, or rather by creating a new -offense, the elements of which were the acts of the criminal. What should have been done was to have amended the definitions which had been proved defective. Thus, the common law definition of larceny did not cover the case where the possessor voluntarily parted with his possession, and so there were statutes passed which.created the offenses, among others, of larceny by bailee, embezzlement, and obtaining goods by false pretences. A single statute eliminating the element of trespass from the definition of larceny would have made unnecessary the creation of these new offenses.

It is now necessary to retrace our steps and to formulate a criminal code which will amalgamate in one definition various co-related offenses. As models to be improved on there are the Criminal Codes of India and Canada. Such a codification and simplification is desirable for many reasons, not the least of which is that the formal charging of offenses will be simplified thereby, for it is obvious that the fewer the elements contained in the defnition of an offense, the fewer the averments necessary in an indictment for such offense, The chances of omitting essentials of the definition are reduced, as are the chances of misdescription of such elements. This codification will be a very difficult task, but well worth the efforts of those interested.

This codification is not to be expected for many years, and attention is now directed towards reform of procedure rather than reform of substantive law. There are two ways of effectuating the desired reforms. One is to simplify the procedure and thereby eliminate the chances of error and mistake, and the other is to cure mistakes as they appear. Thus, to confine our attention to the mode of stating the charge against the accused, it is possible to provide by statute that broad descriptions shall be sufficient, or it is possible to provide that, if an error does appear in the-detailed description required by the present rules, such misdescription shall be immaterial.

Any system of criminal procedure should be a proper compromise between individual rights and social rights. The state demands celerity and sureness in the punishment of the criminal. The individual demands the right to present every defense which 
he can possibly have. The objection to the present system of procedure is that it does not insure to the state its right speedily to punish the guilty criminal. The accused person has too many privileges, more than are necessary for a fair hearing of the accusation against him. The proposition confronting the reformer is to expedite justice and at the same time conserve the rights of the accused person. Assuming that, under the present procedure, the guilty criminal plays with dice loaded in his favor, the writer proposes to discuss the relative merits of the two schemes of insuring that punishment will fall upon the guilty person and that it shall fall speedily after the commission of the offense. The very serious limitations which the constitutions of the various states place upon any reform of procedure are not considered in this discussion. They will, however, be discussed in a subsequent paper.

Both the preventative and the curative schemes will increase the sureness of punishment. So far as the ultimate punishment is concerned, the same result is reached whether the law says there has been no defect in procedure or whether it says that the error which occurred is immaterial. But it is submitted that they will not, to the same degree, accelerate punishment. That this is so is a necessary result of the fact that the individual accused of an offense has a right to be iried according to the rules of law, and there is a perfectly logical presumption that a violation of the rales by the accusing party has operated against the interests of the accused. This presumption of prejudice is perhaps no more than a state of mind of the supposedly imfictial judge, but it is none the less existent. It is supposed that the state has given the accused no more privileges than are necessary to secure a fair trial and the natural inference is that the person deprived of such privileges has been deprived of a fair trial. This places the burden on the state to show that in this particular instance the defendant has not been prejudiced by the error. The natural presumption of prejudice which thus arises, will consciously or unconsciously affect the criminal himself and the trial and appellate courts. The accused will be astute to raise objections, claiming prejudice, and the trial court will tend to sympathize with him. The accused has a hook upon which to hang his appeal and the appellate court is prone to listen 
to him. As an extreme instance of this, it is necessary to look only to those courts which hold that there is a legal presumption of prejudice arising from every violation of procedural rules.

The mental attitude of the courts will be different when a simplified procedure prevents the too frequent appearance of error. Even granting that, in a case out of the ordinary, it will be necessary to give the accused an extraordinary privilege, the burden will be upon the defendant to show that his particular case is out of the ordinary. There is a natural presumption that the procedure is sufficiently technical to guarantee individual rights." The defendant must then prove that he was prejudiced. Unless he has been prejudiced there is nothing upon which he can hang a motion or an appeal. The difference in the mental reaction of the criminal and the courts should make considerable difference in the number of appeals taken, and it is the appeals which clog the wheels of justice more than anything else.

If this element of prejudice to the accused did not exist, each plan would produce the same result; but it does exist and is inherent in the curative scheme. The curative statute may provide that the burden shall be on the person accused to show that he has been prejudiced, but, despite even that specific statement, the feeling of the court and criminal will be to say: "The laws of procedure have been broken, prejudice must have resulted."

It is submitted that any proper scheme of reforming the rules governing indictments should combine both ideas; it should prevent errors by simplifying the allegations of the indictment and it should cure the errors which do appear therein after simplification. There is theoretically no limitation upon the extent to which either idea can be carried. Justice can be done to the man who is tried without any formal charge against him, as is the case now when petty offenses are summarily tried; and it is possible to do justice where the formal charge is written after all the evidence on both sides is in, and the proper legal authority has found the facts. Practically, there are serious limitations upon both methods. Although justice can be done, injustice is too likely to result. It is elemental that an accused person should have an

State v. Lockbaum, 38 Conn. 403 (1871). 
opportunity to prepare a defense and the best way of insuring to him this opportunity is to present a formal charge against him.

Admitting that a formal charge is desirable, how much matter in relation to the offense should be found there? There are two tests which will at once occur to everyone. The first is, that the indictment should so describe the particular offense that no injustice could possibly be done to the innocent man. He should be told so much in regard to the particular offense that he could present every possible defense. This standard is practically impossible. It would require that the indictment should contain all the evidence against the accused. It has never been required under the strictest common law. Thus, at common law, the indictment did not necessarily aver either the exact time or the exact place of the commission of the offense. The accused was, therefore, so far as the formal charge was concerned, unable to prepare before the trial an alibi which would entitle him to an acquittal, except the one that never, prior to the finding of the indictment, had he been within the jurisdiction of the court.

It is submitted that the proper requirement for the allegations of the indictment is that the indictment should aver only so much concerning the offense as is necessary to enable the accused person to present his defense in the normal case. This involves a determination of what is the normal case. To our mind, in the average case, the person who is being prosecuted is the person who, whether guilty or innocent of the crime, does as a matter of fact know at least as much about it as the prosecution. He has had some connection therewith, or suspicion would never have been directed to him. It is possible to presume a man innocent of the offense, and still to presume that he knows a great deal about it. It is upon this assumption that the ordinary trial is conducted. In the average case, the prisoner never sees the formal charge. Upon arraignment, only the salient points are read to him. The clerk says, "John Smith, you are charged with the larceny of a gold watch from John Doe. How say you? Guilty or Not Guilty?" That is all that the defendant hears of the contents of the indictment. His attorney may read the indictment over, but if he does, it is not for the purpose of preparing the defense of the accused, but in order to discover any technical errors that may exist therein. This ordinary procedure is perfectly fair to the accused; thousands 
of persons are tried every year in this manner in Philadelphia County alone, and no person is ever heard to claim that the accused has not had a fair trial. If the practical procedure at present in vogue works justly in the vast majority of cases, it would seem that the only thing to be done is to study the practical workings of our procedure and to enact the normal practice into the model code.

Certain objections will, of course, be raised to the normal case as the standard. It is obvious that the allegations which are sufficient for the securing of a fair trial in the normal case are more than sufficient in a great number of cases and that, in other cases, the same averments are insufficient. A complete code can be devised to meet both these objections. Take the case where the accused knows without the formal charge just what he has to meet, where his counsel knows the law and the prosecuting officer is fair to him; the indictment fails to allege, or alleges incorrectly, certain facts in connection with the offense. In such a case the curative scheme should be put into effect, and the principle upon which the curative statute should be formulated is that any defect in procedure which did not prejudice the substantial rights of the accused should not occasion any delay or mis-trial in the case. Such a statute is operative in many jurisdictions at present, but it does not have the effect which its sponsors hoped for it, because of the presumption of prejudice which arises from every defect in procedure. It is submitted that, if this presumption is permitted to arise only in subnormal cases, it will not seriously hamper the administration of criminal law.

There will also be the class of cases where the allegations of the indictment will be insufficient to secure a fair trial. The codeshould provide extraordinary procedure for this class. It should give to the accused the right to demand the information desirable for his defense. This could be done by an extension of the practice of giving a bill of particulars. The burden should be on the accused to show that the bill of particulars is needed in the particular case, and unless he can show that he deserves these indulgences, he will not be.granted the privilege. The curing of defects and the granting of bills of particulars will, of course, give the judges a great amount of discretionary power, but it remains yet to be shown that the courts are under-zealous in caring for the rights of the accused. 
Any simplification of the indictment necessarily involves change in the standards by which the validity of the formal accusation is to be determined. It will be well to see just what standards are at present applied and to discuss whether they are valid in the sense that the present indictment does conform to them, and whether valid or not if they are unalterable.

Lumpkin, J., in Wingard v. State,' states the standard by which the validity of an indictment is to be judged, in terms of the purposes which it serves, as follows:

"The objects in requiring particularity in setling.out an offense are:

"First, in order to identify the charge, lest the Grand Jury should find a bill for one offense and the defendant be put upon his trial in chief for another.

"Secondly, That the defendant's conviction or acquittal may inure to his subsequent protection should he again be questioned on the same grounds.

"Thirdly, In warranting the court in granting or refusing any particular right or indulgence incident under the law to the case.

"Fourthly, To enable the accused to determine on the line of his defense, and prepare for it, both as to law and facts. And,

"Fifthly, And finally, to put it in the power of the court to look through the record and decide whether the facts charged are sufficient to support a conviction for a particular crime and to warrant the judgment; and also to regulate the appropriate punishment for the particular offense." These are practically the same words found in Chitty.0

The first test given is not applicable to the information because the information is drawn by the same person who prosecutes the case in chief. Nor is it any more necessary when dealing with the indictments, using the term now in its restricted sense. As has. been pointed out before, the public prosecutor himself prepares the indictment, presents the case to the grand jury and then tries the case in the trial court. There is absolutely no danger that he should have the grand jury hear one case and the trial jury another. If he could prove both, he would prefer two indictments. The fact

i2 Ga. 306 (1853).

10 Page 109. 
that the same material witnesses appear belore the grand jury and the petit jury is a sufficient guarantee that the defendant cannot be indicted for one offense and tried for another.

It is not necessary that the indictment be so framed that it should, when pleaded in a subsequent prosecution for the same offense, bar the subsequent prosecution. The law at present permits the accused to offer evidence dehors the indictment to identify the particular offense for which he was formerly prosecuted, and, although it may not be advisable to put him at the mercy of the faulty memory of individuals, it is perfectly possible for the procedure to be so amended as to permit the court to insert the facts as developed at the trial in the record in such a manner as to remedy any deficiencies in the indictment. It is more to the advantage of the accused that the record should be conclusive as to the facts developed at the trial than that it should be conclusive as to the facts alleged in an indictment framed, in all probability, before all the facts of the case were known to the public prosecutor. Even without a specific provision relative to the amplification of the record, it is obvious that the present practice of keeping stenographic notes of the evidence is a sufficient protection for the accused. The pleadings have ceased to be as important as they were when Chitty wrote his book.

The third object in requiring particularity in the indictment is also obsolete, so obsolete that the later cases do not mention it.u The rights and indulgences which were once incident to particular offenses have for the most part disappeared from our law. There are, however, rights of bail dependent upon the nature of the case. If the record of the case contains the technical name of the offense, that is sufficient to inform the judge, learned in the law, of the nature of the offense, that being in these cases the determining factor.

The fifth purpose served by the indictment does not require the great particularity found in the common law indictment. A formal charge which would contain only the technical name of the offense, or a reference to the particular statute defining the offense alleged to have been committed, would be sufficient to enable the court to decide whether the facts proved are sufficient to support a conviction for the offense charged.

"Miller v. U. S., 133 Fed. 337 (1904). 
The principle that the indictment as part of the record regulates the appropriate punishment for the particular offense has to a considerable extent disappeared in practice. Modern criminology apportions the punishment to the individual more than to the offense. Maximum and minimum sentences are legal in most jurisdictions. The proper sentence now, within certain limits, rests in the discretion of the judge, and he determines the sentence for each case upon facts which do not appear in the indictment. He takes into consideration the standing of the individual in the community, his personal characteristics as they. appear in the course of the trial, the character of the defense offered by the accused, and the extenuating circumstances shown by the evidence to have existed in the case. These factors regulate the punishment but do not appear in the indictment at present and never have. It is because these elements which do not appear in the record are the determining factors that the practice is to require that the judge who heard the case should impose the sentence, and not a judge who would be forced to rely entirely upon the record.

It is uniformly held under this fifth standard that where the punishment is dependent upon the value of the property which is the subject of the offense, the indictment should allege this value. The jury of course determines the value, and although the allegation of different values in different counts may assist them in framing their verdict, still there is no prejudice to the defendant in permitting them to find it without the allegation in the indictment if sufficient notice is given him that the value is an element of the punishment. The allegation of a maximum value in an indictment for an offense the punishment for which was to be assessed by the jury at "not more than ten times the injury done to the owner of the animal" is of but little service to either the accused or the jury.12 Without an attorney, the accused would not know that the value determined the punishment; and if he had an attorney, the attorney would know that fact. without the indictment to put him on notice thereof.

It is said that there is one more object in requiring particularity in the setting out of an offense, namely, to enable the accused to determine on the line of his defense and prepare for it

2 Thiomas v. State, 12 Tex. 235 (1875). 
both as to the law and facts. A strict application of this utilitarian test would mean that the indictment which did not allege all the facts, knowledge of which would assist the accused in his defence, would be insufficient. This was never so even at strict common law; as has been pointed out before, a man indicted for ail offense as of a certain time and place was deprived of the alibi as defense so far as the information given by the indictment was concerned. And the latter cases noticing this, say that the indictment must be sufficiently full to give the accused a fair opportunity to present his defense."

The rules which have been formulated to insure to the accused a fair opportunity to prepare his defense seem to be based upon the presumptions that the person accused knows absolutely nothing about the facts constituting the alleged crime, that he knows nothing of the laws forbidding the doing of certain acts and cannot gain that information anywhere but in the indictment, and finally that the accused is of such a peculiar mental make-up that he cannot understand anything but the most direct, certain, and positive statements. He has sufficient mental ability to struggle with long involved sentences and clauses with legal terminology not in the common use, but he is unable to understand the fair inference of the words used, if by a far stretch of a most vivid imagination they can be made to bear an innocent interpretation. To state these presumptions is to show how unnecessary they are. The accused person usually has full information as to the particular transaction which has got him into trouble; in another connection the law says that "Ignorantia legis neminem excusat" and the defendant is usually as capable of drawing a fair inference as is the average person.

It is submitted that a new code prescribing the rules governing indictments should be drawn without regard to these five standards which the common law has set up. The formal accusation under the reformed code should contain only so much matter as is necessary to insure a fair trial in the ordinary case.

The task of the person who would formulate a model statute governing indictments is not concluded with the adoption of this standard. He has still to determine what is the normal case and

u Miller v. U. S., 133 Fed. 337 (1904). 
what averments are required for a fair trial in such a case. To do this, he should go into the trial courts of the various jurisdictions, he should study the rules governing indictments at common law, the varius statutes which modify the rules of the common law, and the codes which are supposed to be complete in themselves. The manner in which these rules are applied both in the trial courts and in the appellate courts must also be studied. The writer has devoted a considerable time to comparative study of the common law and the statutes and the cases found in the books. The results of his study will be presented in another paper.

L. Pearson Scols.

University of Pernsyloania, April, 1913. 